\title{
IMPOR BERAS DALAM KEBIJAKAN HUKUM EKONOMI ISLAM: KEINGINAN ATAU KEBUTUHAN
}

\author{
Ahmad Dakhoir, Novi Angga Safitri, dan Khoiriyah \\ Institut Agama Islam Negeri (IAIN) Palangka Raya \\ Email: ahmad.dakhoir@iain-palangkaraya.ac.id
}

\begin{abstract}
Abstrak
Beras merupakan bahan makanan pokok utama rakyat Indonesia. Kebutuhan beras dari tahun ke tahun terus meningkat karena kenaikan jumlah penduduk dan kebutuahan ini harus terpenuhi. Kekurangan pangan berpengaruh pada gizi buruk, kesehatan, dan sekaligus menurunkan kualitas sumberdaya manusia. Oleh karena itu, pemerintah senantiasa terus berupaya untuk memiliki serta memelihara ketahanan pangan khususnya beras. Tulisan ini akan menganalisis berdasarkan informasi yang ada, apakah inpor yang dilakukan pemerintah adalah suatu kebutuhan atau keinginan?Penelitian ini menggunakan metode analisis isi kualitatif dimana peneliti berusaha mengkonstruksi realitas dan memahami maknanya sehingga penelitian ini sangat memperhatikan proses, peristiwa, dan otensitas. Hasil analisis tersebut, yaitu: (1) Impor beras merupakan kebutuhan karena beberapa hal, yaitu kekurangan stok beras pada suatu negara atau memerlukan beras yang menyehatkan bagi masyarakat. (2) Impor beras menjadi hanya sebuah kepentingan jika hanya segelintir orang yang merasakannya. (3) Saran yang dapat penulis berikan adalah, sebaiknya pemerintah memberikan berhatian lebih kepada para petani, seperti menyediakan lahan, bibit, pupuk, dan sebagainya. Dan mendukung petani dalam menjual berasnya, dengan mengatur harga beras dipasaran.
\end{abstract}

\section{Kata Kunci: impor beras, kebutuhan, keinginan}

\section{PENDAHULUAN}

Beras merupakan bahan makanan pokok utama rakyat Indonesia. Kebutuhan beras dari tahun ke tahun terus meningkat karena kenaikan jumlah penduduk dan kebutahan ini harus terpenuhi. Kekurangan pangan berpengaruh pada gizi buruk, kesehatan, dan sekaligus menurunkan kualitas sumberdaya manusia. Olehkarena itu, pemerintah senantiasa terus berupaya untuk memiliki serta memelihara ketahanan pangan khususnya beras. Namun seiring dengan usaha tersebut di dalam operasionalnya, masalah vital yang dihadapi saat ini adalah adanya alih fungsi lahan sawah. ${ }^{1}$

Komoditas beras masih mempunyai peranan yang strategis baik sebagai komoditas politis maupun ekonomi. Implikasinya adalah diperlukan adanya upaya penyediaan pangan (beras) yang diikuti dengan pendistribusian yang memadai. ${ }^{2}$ Kebijakan tentang perberasan sangat sarat dengan berbagai kepentingan, sehingga banyak keputusan yang diambil oleh pemerintah cenderung mengarah pada kepentingan jangka pendek, seperti masalah harga pembelian pemerintah, impor dan kebijakan jangka pendek lainnya. Kalau diperhatikan secara seksama ada empat persoalan mendasar dalam masalah perberasan, yaitu : (1) lemahnya akurasi data;

\footnotetext{
${ }^{1}$ Santosa, I., Gede, M. A., Ketut, I., \& Dinata, K. (2011). Dampak alih fungsi lahan sawah terhadap ketahanan pangan beras.

${ }^{2}$ Kariyasa, K. (2017). Dampak tarif impor dan kinerja kebijakan harga dasar serta implikasinya terhadap daya saing beras Indonesia di pasar dunia. Analisis Kebijakan Pertanian, 1(4), 315-330.
} 
(2) miskinnya petani padi; (3) besarnya ketergantungan terhadap beras; dan (4) masalah harga serta distribusi beras. ${ }^{3}$

Direktur Utama Perum Bulog Budi Waseso (Buwas) mengatakan stok beras yang dimilikinya saat ini berjumlah 2,4 juta ton. Hingga akhir tahun, diperkirakan stok beras Bulog mencapai 2,3 juta ton. Buwas mengatakan bahwa dengan jumlah tersebut, maka tidak diperlukan impor beras lagi tahun ini. Ia menambahkan, pihaknya saat ini sudah mendapatkan 1,4 juta beras impor di tahun ini. Ia juga menegaskan untuk tidak melakukan impor lagi. ${ }^{4}$ Dengan demikian tulisan ini akan menganalisis berdasarkan informasi yang ada, apakah inpor yang dilakukan pemerintah adalah suatu kebutuhan atau keinginan?

\section{METODE PENELITIAN}

Penelitian kualitatif dipengaruhi oleh paradigma naturalistik-interpretatif. Dimana peneliti berusaha mengkonstruksi realitas dan memahami maknanya sehingga penelitian ini sangat memperhatikan proses, peristiwa, dan otensitas. Menggunakan metode analisis isi harus mengamati fenomena komunikasi, dengan merumuskan dengan tepat apa yang diteliti dan semua tindakan harus didasarkan pada tujuan tersebut. Selanjutnya memilih unit analisis yang akan dikaji, memilih objek penelitian yang menjadi sasaran analisis. Apabila objek penelitian berhubungan dengan data-data verbal maka perlu disebutkan tempat, tanggal dan alat komunikasi yang bersangkutan. Namun, kalau objek penelitian berhubungan dengan pesanpesan satu dalam suatu media, perlu dilakukan identifikasi terhadap pesan dan media yang mengantarkan pesan itu. ${ }^{5}$

\section{HASIL DAN PEMBAHASAN}

\section{Kebijakan Hukum Ekonomi}

Kebijakan ekonomi secara makro terbagi menjadi dua yaitu kebijakan fiskal dan kebijakan moneter. Menurut Rahardja dan Manurung (2001), kebijakan fiskal adalah kebijakan ekonomi yang digunakan pemerintah untuk mengelola atau mengarahkan perekonomian ke kondisi yang lebih baik atau di inginkan dengan cara mengubah-ubah penerimaan (pajak) dan pengeluaran pemerintah. Sedangkan kebijakan moneter adalah upaya mengendalikan atau mengarahkan perekonomian makro kekondisi yang lebih baik dengan mengatur jumlah uang beredar. Adapun yang dimaksud dengan kondisi lebih baik adalah meningkatnya output keseimbangan dan terpeliharanya stabilitas harga. ${ }^{6}$

Dalam kebijakan fiskal, tugas utama pemerintah adalah untuk meningkatkan pertumbuhan ekonomi dan menyediakan lapangan kerja yang luas bagi masyarakat. Kebijakan ini lebih bersifat langsung menyentuh sektor riil. Kebijakan fiskal di Indonesia tercermin dari Anggaran pendapatan dan Belanja Negara (APBN). Dari APBN, bisa dilihat kebijakan anggaran apa yang diterapkan di Indonesia. Selain itu pos belanja negara mengalami penambahan pos yaitu dana perimbangan yang merupakan dana untuk desentralisasi daerah. Dalam struktur APBN, pemerintah dapat menerapkan anggaran defisit sejauh hal ini diperlukan dalam meningkatkan aktivitas perekonomian. Anggaran defisit adalah anggaran di mana komposisi pengeluaran lebih besar dari penerimaan. Sumber pembiayaan anggaran defisit dapat berupa

\footnotetext{
${ }^{3}$ Jamal, E., Ariningsih, E., Hendiarto, H., Noekman, K. M., \& Askin, A. (2016). Beras dan Jebakan Kepentingan Jangka Pendek. Analisis Kebijakan Pertanian, 5(3), 224-238.

${ }^{4}$ https://finance.detik.com/berita-ekonomi-bisnis/d-4218840/stok-beras-bulog-24-juta-ton-buwas-jangan-ada-impor-lagi

${ }^{5}$ https://www.researchgate.net/profile/Jumal_Ahmad/publication/325965331_Desain_Penelitian_Analisis_Isi_Content_Analysis/lin ks/5b305090a6fdcc8506cb8b21/Desain-Penelitian-Analisis-Isi-Content-Analysis.pdf

${ }^{6}$ Seftarita,Chenny.(2014).Kebijakan Ekonomi Makro Dan Siklus Bisnis; Kajian Teori Dan Studi Empiris.Syiah Kuala University Press.Banda Aceh.(No ISBN: 978-602-1270-10-3)
} 
utang luar negeri maupun utang dalam negeri. Selain kebijakan anggaran defisit, dikenal juga istilah anggaran berimbang di mana pengeluaran adalah sama dengan penerimaan, dan anggaran surplus di mana pengeluaran lebih kecil dari penerimaan. ${ }^{7}$

Kebijakan pemerintah yang kedua adalah kebijakan moneter. Di Indonesia, kebijakan moneter diserahkan sepenuhnya pada Bank Indonesia yang merupakan pihak otoritas moneter. Pasca krisis moneter tahun 1997/1998 banyak pembenahan terjadi dalam tubuh Bank Indonesia. Salah satunya yaitu independensi, tugas dan wewenangnya. Perubahan ini diatur dalam UU No. 23 Tahun 1999 tentang Bank Indonesia, yang diberlakukan pada tanggal 17 Mei 1999 dan kemudian diubah dengan Undang-Undang Republik Indonesia No.6 Tahun 2009. Dalam undang-undang ini diatur tentang status dan kedudukan Bank Indonesia sebagai suatu lembaga negara yang independen dalam melaksanakan tugas dan wewenangnya, bebas dari campur tangan pemerintah dan/atau pihak lain, kecuali untuk hal-hal yang secara tegas diatur dalam undang-undang ini. Hal lain adalah menyangkut tujuan dan tugas utama Bank Indonesia yang saat ini terfokus pada pencapaian dan pemeliharaan stabilitas nilai rupiah. Untuk mencapai stabilitas rupiah tersebut, instrumen moneter yang menjadi sasaran antara adalah jumlah uang beredar (Money Supply), dan tingkat bunga (interest). Sedangkan sasaran akhir yang hendak dicapai adalah kestabilan nilai rupiah meliputi inflasi dan nilai tukar. ${ }^{8}$

Ada beberapa istilah dalam kebijakan, jika yang dilakukan adalah menambah jumlah uang beredar, maka pemerintah dikatakan menempuh kebijakan moneter ekspansif (monetary expansive). Sebaliknya jika jumlah uang beredar dikurangi, maka pemerintah (Bank sentral) menempuh kebijakan moneter kontraktif (monetary contractive). Dalam jangka panjang kebijakan moneter hanya berdampak pada inflasi, dan tidak banyak pengaruhnya terhadap kegiatan ekonomi riil, dalam jangka pendek kebijakan moneter ekspansif dapat mendorong kegiatan ekonomi yang sedang mengalami resesi yang berkepanjangan. Sebaliknya kebijakan moneter kontraktif dapat memperlambat laju inflasi yang umumnya terjadi pada saat kegiatan perekonomian sedang mengalami booming. ${ }^{9}$

\section{Kebijakan Impor Beras Indonesia 2018}

Semua peraturan atau kebijakan tetang ketahanan pangan nasional dapat dilihat pada Peraturan Presiden Republik Indonesia Nomor 48 Tahun 2016 tentang Penugasan Kepada Perusahaan Umum (Perum) Bulog Dalam Rangka Ketahanan Pangan Nasional. Rakortas yang dilakukan untuk memutuskan kebijakan impor juga di dasarkan pada PerPres ini.

Pemerintah melalui hasil rapat koordinasi terbatas (rakortas) yang melibatkan kementerian dan lembaga terkait memutuskan impor beras secara bertahap sepanjang tahun ini, dengan total 2 juta ton. Hasil rakortas diputuskan semua kementerian dan lembaga di bawah koordinasi Kementerian Koordinator Bidang Perekonomian. Belakangan, perihal impor beras jadi polemik karena Kementerian Pertanian mengklaim produksi beras dalam negeri mencukupi kebutuhan hingga akhir tahun. Sedangkan harga beras di pasaran sempat naik dan stok beras pemerintah di Perum Bulog yang digunakan untuk operasi pasar pun jumlahnya minim. Dalam rapat di awal tahun 2018 terjadi debat dari berbagai pihak, di mana ada yang yakin produksi beras cukup untuk kebutuhan tahun 2018 dan ada yang meragukannya. Hingga rapat berikutnya kembali digelar 15 Januari, dan dicek stok beras di Bulog saat itu tinggal 903.000 ton. Tambahan stok beras dalam negeri biasanya menunggu masa puncak panen raya yang jatuh pada Maret atau April. Sementara, dengan stok beras yang tidak seberapa dan masih bulan Januari, dengan

Ibid 
kondisi harga di pasaran sudah naik, maka hasil rakortas memutuskan impor 500.000 ton beras. Kementerian Pertanian dalam rakortas memproyeksikan total hasil produksi beras dari panen raya bisa mencapai 13,7 juta ton, dengan perkiraan produksi 2,5 juta ton pada Januari, 4,7 juta ton pada Februari, dan 6,5 juta ton pada Maret. Namun saat rapat berikutnya tanggal 19 Maret, stok beras di Bulog tinggal 590.000 ton dengan kondisi 500.000 beras impor hasil keputusan rapat Januari belum masuk. Rakortas terakhir turut memutuskan bahwa Bulog harus menyerap beras hasil produksi dalam negeri paling lambat bulan Juni sebesar 2,2 juta ton. Sementara saat rapat berikutnya tanggal 28 Maret, stok beras Bulog baru naik sedikit, menjadi 649.000 ton dari posisi terakhir 590.000 ton per 19 Maret. Belakangan harga beras masih tinggi, yaitu Rp 11.036 per kilogram untuk beras medium dan di sisi lain operasi pasar terus dilakukan. Kemudian rakortas memutuskan kembali menambah impor beras hingga total untuk tahun ini 2 juta ton. Setelah berbagai keputusan itu, dalam rapat terakhir di bulan Agustus, jumlah stok beras di Bulog sudah ada 2,2 juta ton. Namun, jumlah itu termasuk dengan beras impor yang sudah masuk sebesar 1,4 juta ton. Dari total 1,4 juta ton beras impor yang sudah masuk, maka seharusnya masih ada 600.000 ton beras lagi. Tapi, dipastikan itu tidak jadi diimpor karena kendala teknis dari negara produsen dan proses pengiriman yang membuatnya melebihi batas waktu yang ditentukan dalam rakortas. Upaya pemerintah menjaga harga kebutuhan pokok, termasuk beras, tercermin dari Indeks Harga Konsumen (IHK) atau inflasi. ${ }^{10}$

\section{Impor Beras Indonesia Tahun 2018}

Pemerintah memberi kuota impor beras untuk Perum Bulog 2 juta ton. Dari Januari hingga Agustus 2018, Bulog telah impor telah mencapai 1,4 juta ton beras. Berdasarkan data Badan Pusat Statistik (BPS), nilai impor beras tersebut mencapai US\$ 700 juta dengan total 1.498.930.500 ton. Rinciannya, impor beras di Februari sebanyak 230.800 ton, Maret 44.934 ton, April 122.600 ton, Mei 294.600 ton. Kemudian Juni sebanyak 172.581,5 ton, Juli 316.208 ton, dan Agustus 317.203 ton. Sebelumnya, Direktur Utama Perum Bulog Budi Waseso (Buwas) mengatakan saat ini beras di gudang ada sebanyak 2,4 juta ton. Stok tersebut pun membuat gudang Bulog penuh. Bahkan, Bulog mesti menggelontorkan dana hingga Rp 45 miliar untuk menyewa gudang milik TNI/Polri di daerah. ${ }^{11}$

Kementerian Perdagangan (Kemendag) membuka keran impor beras. Beras tersebut merupakan beras khusus dari Thailand dan Vietnam dengan jumlah mencapai 500 ribu ton. Menteri Perdagangan Enggartiasto Lukita menyatakan, beras khusus tersebut bisa bermacammacam jenisnya, seperti beras jasmine, beras ponni, beras basmati dan lain sebagainya. Namun dia memastikan beras yang diimpor tersebut bukan jenis IR64 yang diproduksi di Indonesia. Sebelumnya, Kemendag memutuskan untuk membuka keran impor beras khusus. Hal tersebut dilakukan untuk menjamin ketersediaan beras di dalam negeri dan sebagai salah satu langkah untuk menekan harga beras di pasaran. Beras tersebut dipasok dari dua negara yaitu Thailand dan Vietnam. Namun dia memastikan beras yang diimpor tersebut bukan jenis beras yang sudah mampu diproduksi di Indonesia. Menurut dia, impor ini dilakukan guna mengisi pasokan beras di dalam negeri sambil menunggu masa panen pada Februari-Maret 2018. Dengan adanya tambahan beras impor ini diharapkan tidak ada kekhawatiran soal kelangkaan dan kenaikan harga beras. ${ }^{12}$

\footnotetext{
${ }^{10 h t t p s: / / e k o n o m i . k o m p a s . c o m / r e a d / 2018 / 09 / 20 / 060500926 / f a k t a-d i-b a l i k-r e n c a n a-i m p o r-b e r a s-2-j u t a-t o n-t a h u n-i n i ~ d i a k s e s ~}$ pada 15 Nov 2018.

${ }^{11}$ https://finance.detik.com/berita-ekonomi-bisnis/d-4217650/bulog-impor-14-juta-ton-beras-hingga-agustus-2018 diakses pada 14 Nov 2018.

${ }^{12}$ https://www.liputan6.com/bisnis/read/3223311/kemendag-buka-keran-impor-beras-khusus-jenis-apa-saja diakses pada 14 Nov 2018.
} 


\section{Kebijakan Hukum Ekonomi Islam tentang Impor Beras}

Jumlah kebutuhan beras yang dibutuhkan untuk memenuhi kebutuhan konsumsi dan stok cadangan beras dalam negeri serta upaya dalam mencapai swasembada pangan dan menjaga kelancaran distribusi beras kepada masyarakat. ${ }^{13}$ Tingkat keuntungan (profitabilitas) yang relatif tinggi mendukung pemberdayaan petani padi, menjaga motivasi dalam usaha tani padi, mendukung peningkatan produksi padi secara konsisten dan ketersediaan pasokan pangan (beras) guna mewujudkan ketahanan pangan. ${ }^{14}$

Negara berkembang adalah importir utama dari pertanian dan makanan produk-produk dari negara-negara berkembang. Sementara perdagangan internasional komoditas pertanian telah berkembang, telah tumbuhnya kesadaran oleh konsumen tentang kualitas produk makanan impor. ${ }^{15}$ Teknologi baru telah menghasilkan beras yang berkhasiat mengurangi kekurangan vitamin dan mineral. ${ }^{16}$ Dengan cepat mengubah ukuran demografis dan struktur Asia akan membawa dampak besar pada sifat dan organisasi beras di masa depan pertanian dan ketahanan pangan. ${ }^{17}$ Pasar dunia dapat dipercaya untuk memainkan peran penting dalam memberikan ketahanan pangan di Indonesia. ${ }^{18}$ Peningkatan produksi beras dan stok beras serta peningkatan kurs menurunkan impor beras sedangkan peningkatan konsumsi menaikkan impor beras. ${ }^{19}$ Pengelolaan persediaan beras pada Perum Bulog harus memperhatikan kondisi pengadaan dalam negeri dan penyaluran beras, sedangkan impor beras hanya sebagai komplemen dan jika terpaksa dilakukan. ${ }^{20}$

Kamboja dan Thailand memiliki daya dukung lahan pertanian dalam memproduksi beras untuk memenuhi kebutuhan penduduknya paling baik. Malaysia mampu menjadikan usaha tani padi memberikan kehidupan yang layak bagi petaninya, sementara usaha tani di Indonesia belum mampu memberikan kehidupan yang layak bagi petani, karena rata-rata luas garapan padi di Indonesia sangat sempit, sekalipun teknologi produksi padi yang diterapkan petani Indonesia sudah cukup intensif, dibawah China, Korea, Jepang, Vietnam. ${ }^{21}$ Mengembangkan industri berbasis beras di Malaysia dan efek pada situasi pasar beras, beras impor kuota mungkin memiliki dampak negatif pada peningkatan pendapatan petani, harga bisa mampu yang lebih bagi konsumen, dan diversifikasi makanan di Malaysia. ${ }^{22}$ Pasokan beras dunia sangat tak terduga. Produksi berfluktuasi karena faktor alam, kekeringan, banjir, dan topan, dan kurang dari lima persen produksi beras dunia diperdagangkan secara internasional. ${ }^{23}$ Populasi yang terdapat pada beras yang beresiko tinggi kekurangan vitamin dan mineral. Teknologi

\footnotetext{
13 Widiarsih, D. (2013). Pengaruh sektor komoditi beras terhadap inflasi bahan makanan. Jurnal Sosial Ekonomi Pembangunan, 2(6).

14 Abidin, M. Z. (2015). Dampak kebijakan impor beras dan ketahanan pangan dalam perspektif kesejahteraan sosial. Sosio Informa.

15 Kallummal, M., Mendiratta, D., \& Samgita, S. (2018).US Import Refusals of Agricultural Products and Their Impact on the Participation of Indian Firms. Journal of Political Economy, 7(I) 78-104

${ }^{16}$ Muthayya, S., Hall, J., Bagriansky, J., Sugimoto, J., Gundry, D., Matthias, D., Prigge, S., Hindle, P., Moench-Pfanner, R., and Glen M Aberly. (2012). Rice fortification: An emerging opportunity to contribute to the elimination of vitamin and mineral deficiency worldwide.Food and Nutrition Bulletion,Vol. 33, no.4.The United Nations University.

${ }^{17}$ Bhandari, H., \& Mishra. (2018). Impact of Demographic Transformationon Future Rice Farming in Asia. Outlook on Agriculture I-8.

18 David Dawe (2008) CAN INDONESIA TRUST THE WORLD RICE MARKET?, Bulletin of Indonesian Economic Studies, 44:1, 115-132, DOI: $10.1080 / 00074910802008053$.

${ }^{19}$ Rungkat, D. M., Rumagit, G. A., Ngangi, C. R., \& Ruauw, E. (2014, February). Analisis Faktor-faktor yang Mempengaruhi Impor Beras di Sulawesi Utara. In COCOS (Vol. 4, No. 2).

${ }^{20}$ Wijayanti, S., Candra, S., \& Sarjono, H. (2011). Analisis Persediaan Beras Nasional Dalam Memenuhi Kebutuhan Beras Nasional pada Perusahaan Umum BULOG. The Winners, 12(1), 82-96.

${ }^{21}$ Suryana, A., \& Kariyasa, K. (2016, August). Ekonomi padi di Asia: Suatu Tinjauan Berbasis Kajian Komparatif. In Forum Penelitian agro ekonomi (Vol. 26, No. 1, pp. 17-31).

${ }^{22}$ Dordkeshan, M.J., Shamsudin, M.N., Mohamed, Z., \& Radam, A., Assessing the Impact of Rice Import Quota Policy on the Malaysian Rice Sector. (2017). Journal of Food Products Marketing, DOI: 10.1080/10454446.2017.1244798

23 Jonna P. Estudillo , Manabu Fujimura \& Mahabub Hossain (1999) New Rice Technology And Comparative Advantage in Rice Production in the PHILIPPINES, The Journal of Development Studies, 35:5, 162-184, DOI: 10.1080/00220389908422596.
} 
ditingkatkan untuk membentengi beras memiliki potensi untuk mengatasi kekurangankekurangan ini dan dampak kesehatan yang merugikan. ${ }^{24}$

Kebijakan harga beras murah tidak dianjurkan, karena bukti-bukti empiris menunjukkan bahwa kebijakan ini telah menyengsarakan petani padi dan tidak mampu mendorong sektor industri untuk mampu bersaing di pasar dunia. Kebijakan stabilitas harga beras di pasar domestik yang berorientasi pada peningkatan pendapatan petani, merupakan paket kebijakan yang sangat diperlukan petani padi saat ini. ${ }^{25}$ Pemerintah sebaiknya tidak menerapkan kebijakan yang akan meningkatkan harga beras dalam negeri dan lebih berfokus kepada upaya peningkatan produksi beras nasional. ${ }^{26}$ Kebijakan yang umum ditempuh adalah memajaki ekspor dengan alasan untuk memupuk penerimaan pemerintah, tidak peduli dengan perluasan pasar. Padahal, hasil pajak ekspor tersebut tidak jelas pemanfaatannya untuk membantu petani produsen. ${ }^{27}$

Faktor yang mempengaruhi penurunan produktivitas pertanian adalah kenaikan hargaharga input dalam proses produksi padi, seperti bibit, pupuk dan alat-alat produksi lainnya serta penggunaan teknologi pertanian yang masih kurang, kurangnya pengetahuan petani dalam pengembangan budi daya pertanian dan masih kurangnya bimbingan dari pemerintah dalam pengembangan budi daya pertanian. ${ }^{28}$

Kebijakan konversi lahan sawah tersebut perlu diarahkan untuk mencapai tiga sasaran yaitu: (1) menekan intensitas faktor ekonomi dan sosial yang dapat merangsang konversi lahan sawah, (2) mengendalikan luas, lokasi, dan jenis lahan sawah yang dikonversi dalam rangka menekan potensi dampak negatif yang ditimbulkan, dan (3) menetralisir dampak negatif konversi lahan sawah melalui kegiatan investasi yang melibatkan dana masyarakat terutama kalangan swasta pelaku konversi lahan. ${ }^{29}$ Alih fungsi lahan sawah sulit dihentikan, usaha untuk mempertahankan atau memelihara ketahanan pangan beras ke depan akan semakin sulit, sinergi komponen-komponen antara luas baku lahan sawah, penterapan paket teknologi peningkatan produksi dan pengendalian jumlah penduduk masih belum mantap. Oleh karena itu sangat perlu ada sawah abadi, regulasi untuk melindungi lahan sawah, dan perlu dibuat model sinergi antara luas lahan sawah, penerapan paket teknologi dan jumlah penduduk sehingga ketahanan pangan tetap terjaga. ${ }^{30}$ Faktor penyebab sawah konversi untuk bebas sawah (berubah menjadi tanggul) termasuk produktivitas rendah sawah, rendah kualitas tanah, dan nilai-nilai ekonomi yang lebih tinggi dari tanah milik pesaing. ${ }^{31}$

Kebijakan tarif impor telah berdampak terhadap distribusi pendapatan diantara pelaku pasar. Berkurangnya surplus konsumen, meningkatnya surplus produsen, serta adanya kerugian sosial. Seiring dengan besarnya tingkat tarif yang diberlakukan. Akan tetapi untuk penerimaan pemerintah akan meningkat seiring dengan meningkatnya tarif yang diberlakukan, dan setelah mencapai equilibrium akan mengalami penurunan dan berlawanan arah dengan kenaikan tarif.

\footnotetext{
${ }^{24}$ Muthayya, S., Sugimoto, J. D., Montgomery, S., \& Maberly, G. F. (2014). An Overview Of Global Rice Production, Supply, Trade, And Consumption. Annals of the New York Academy of Sciences, 1324(1), 7-14.

${ }^{25}$ Malian, A. H., Mardianto, S., \& Ariani, M. (2016). Faktor-faktor yang Mempengaruhi Produksi, Konsumsi dan Harga Beras serta Inflasi Bahan Makanan. Jurnal Agro Ekonomi, 22(2), 119-146

${ }^{26}$ Azziz, A. A. (2006). Analisis Impor Beras Serta Pengaruhnya Terhadap Harga Beras Dalam Negeri.

${ }^{27}$ Sawit, M. H. (2016). Praktek Subsidi Ekspor Beras Di Negara Lain: Mungkinkah Diterapkan di Indonesia?. Analisis Kebijakan Pertanian, 7(3), 231-247.

${ }^{28}$ Siringo, H. B., \& Daulay, M. (2014). Analisis Keterkaitan Produktivitas Pertanian Dan Impor Beras Di Indonesia. Jurnal Ekonomi dan Keuangan, 2(8).

${ }^{29}$ Irawan, B. (2016, August). Konversi Lahan Sawah: Potensi Dampak, Pola Pemanfaatannya, Dan Faktor Determinan. In Forum Penelitian Agro Ekonomi (Vol. 23, No. 1, pp. 1-18).

${ }^{30}$ Santosa, I., Gede, M. A., Ketut, I., \& Dinata, K. (2011). Dampak Alih Fungsi Lahan Sawah Terhadap Ketahanan Pangan Beras.

${ }^{31}$ Norliani, \& Rosada, I.,.(2015).Rice-Field Conversion and Its Impact on Food Availability.International Conference on Food, Agriculture and Natural Resources Science Procedia 9 ( 2016 ) 40 - 46
} 
Secara umum dapat dilihat, kebijakan tarif impor telah mengurangi kesejahteraan masyarakat. Agar komoditas beras tetap mempunyai daya saing maka efisiensi biaya produksi perlu ditingkatkan sehingga besarnya tarif impor berangsur-angsur bisa dikurangi sampai titik nol, dengan demikian tingkat kesejahteraan masyarakat yang optimal bisa tercapai. ${ }^{32}$ Tingginya volume impor beras ini dapat disebabkan oleh beberapa faktor, yaitu produksi beras dalam negeri, harga beras dunia dan jumlah konsumsi beras per kapita masyarakat Indonesia. ${ }^{33}$

Berdasarkan fenomena yang terjadi terhadap impor beras Indonesia pada tahun 2018, terdapat folemik antar pengurus yang terlibat didalamnya. Menteri pertanian mengatakan bahwa produk beras memenuhi hingga akhir tahun 2018, sedangkan harga beras di pasaran sempat naik dan stok beras pemerintah di Perum Bulog yang digunakan untuk operasi pasar pun jumlahnya minim sehingga mentri perdagangan memutuskan untuk impor beras. Dilain sisi bulog sebagai perusahaan umum yan dipercaya pemerinah untuk merealisasikan impor menyatakan kekurangan gudang karena stok beras digudang bulog penuh, sehinggan membuat bulog harus menyewa gudang milik TNI/Polri seharga 45Miliar. Hal ini pun membuat para petani protes, karena impor dilakukan pada saat musim panen.

BPS juga perlu melakukan berbagai penyesuaian data-data dan indikator ekonomi lainnya. Ini penting karena data adalah pangkal semua kebijakan publik di mana pun di dunia. Jika data yang digunakan sebagai dasar membuat kebijakan publik salah, kebijakan yang dibuat potensial keliru. Jika kebijakan yang keliru itu menyangkut hajat hidup orang banyak, seperti impor beras, tentu potensial menyengsarakan banyak orang. ${ }^{34}$

\section{PENUTUP}

Berdasarkan hasil diskusi,maka dapat kita simpulkan beberapa hal sebagai berikut.

- Impor beras merupakan kebutuhan karena beberapa hal, yaitu kekurangan stok beras pada suatu negara ataumemerlukan beras yang menyehatkan bagi masyarakat. Penyebab kekurangan stok beras bisa diakibatkan karena lahan yang sempit, atau lahan yang telah beralih fungsi menjadi perumahan atau insfrastruktur, kurangnya perhatian pemerintah terhadap petani seperti penyediaan bibit yang unggul, pupuk yang baik, dan sebagainya.

- Impor beras menjadi hanya sebuah kepentingan jika hanya segelintir orang yang merasakannya. Orang-orang yang sudah melakukan kerjasama dengan pihak pengimpor, sehingga dia tidak peduli apakah negara memputuhkan atau tidak yang penting impor demi kelancaran bisnisnya. Atau orang-orang yang suka menimbun beras, sehingga beras menjadi langka dan harganya mahal sehingga perlunya impor. Ini juga bisa terjadi karena kesalahan atau manipulasi data beras di lapangan.

- Saran yang dapat penulis berikan adalah, sebaiknya pemerintah memberikan perhatian lebih kepada para petani, seperti menyediakan lahan,bibit, pupuk, dan sebagainya, karena negara Indonesia adalah negara agraris yang mempunyai lahan cukup luas untuk penanaman bahan pokok makanan. Dan mendukung petani dalam menjual berasnya, dengan mengatur harga beras dipasaran.Hendaknya penerintak bersinergi dalam memutuskan suatu kebijakan dan lebih mementingkan kepentingan rakyat.

\footnotetext{
${ }^{32}$ Kariyasa, K. (2017). Dampak tarif impor dan kinerja kebijakan harga dasar serta implikasinya terhadap daya saing beras Indonesia di pasar dunia. Analisis Kebijakan Pertanian, 1(4), 315-330.

${ }^{33} \mathrm{Christianto,} \mathrm{E.} \mathrm{(2013).} \mathrm{Faktor} \mathrm{yang} \mathrm{memengaruhi} \mathrm{volume} \mathrm{impor} \mathrm{beras} \mathrm{di} \mathrm{indonesia.} \mathrm{Jurnal} \mathrm{JibekaVolume,} \mathrm{7(2),} \mathrm{38-43.}$

${ }^{34}$ https://geotimes.co.id/kolom/ekonomi/impor-beras-dan-validitas-data/
} 


\section{DAFTAR ISI}

Aberly. (2012). Rice fortification: An Emerging Opportunity To Contribute To The Elimination Of Vitamin And Mineral Deficiency Worldwide. Food and Nutrition Bulletion,Vol. 33, no.4.The United Nations University.

Abidin, M. Z. (2015). Dampak Kebijakan Impor Beras Dan Ketahanan Pangan Dalam Perspektif Kesejahteraan Sosial. Sosio Informa.

Azziz, A. A. (2006). Analisis Impor Beras Serta Pengaruhnya Terhadap Harga Beras Dalam Negeri.

Bhandari, H., \& Mishra.(2018). Impact of Demographic Transformation On Future Rice Farming in Asia.Outlook on Agriculture I-8.

Christianto, E. (2013). Faktor yang Memengaruhi Volume Impor Beras Di Indonesia. Jurnal Jibeka Volume, 7(2), 38-43.

David Dawe. (2008) CAN INDONESIA TRUST THE WORLD RICE MARKET?, Bulletin of Indonesian EconomicStudies, 44:1, 115-132, DOI: 10.1080/00074910802008053.

Dordkeshan, M.J., Shamsudin, M.N., Mohamed,Z., \& Radam, A.,. Assessing the Impact of Rice Import Quota Policy on the Malaysian Rice Sector. (2017). Journal of Food Products Marketing, DOI: 10.1080/10454446.2017.1244798.

https://ekonomi.kompas.com/read/2018/09/20/060500926/fakta-di-balik-rencana-imporberas-2-juta-ton-tahun-ini diakses pada 15 Nov 2018.

https://finance.detik.com/berita-ekonomi-bisnis/d-4217650/bulog-impor-14-juta-ton-berashingga-agustus-2018 diakses pada 14 Nov 2018.

https://finance.detik.com/berita-ekonomi-bisnis/d-4218840/stok-beras-bulog-24-juta-tonbuwas-jangan-ada-impor-lagi.

https://geotimes.co.id/kolom/ekonomi/impor-beras-dan-validitas-data/.

https://www.liputan6.com/bisnis/read/3223311/kemendag-buka-keran-impor-beras-khususjenis-apa-saja diakses pada 14 Nov 2018.

https://www.researchgate.net/profile/Jumal_Ahmad/publication/325965331_Desain_Penelitia n_Analisis_Isi_Content_Analysis/links/5b305090a6fdcc8506cb8b21/Desain-PenelitianAnalisis-Isi-Content-Analysis.pdf

Irawan, B. (2016, August). Konversi Lahan Sawah: Potensi Dampak, Pola Pemanfaatannya, Dan Faktor Determinan. In Forum Penelitian Agro Ekonomi (Vol. 23, No. 1, pp. 1-18).

Jamal, E., Ariningsih, E., Hendiarto, H., Noekman, K. M., \& Askin, A. (2016). Beras dan Jebakan Kepentingan Jangka Pendek. Analisis Kebijakan Pertanian, 5(3), 224-238.

Jonna P. Estudillo , Manabu Fujimura \& Mahabub Hossain (1999) New Rice Technology And Comparative Advantage In Rice Production in the Philippines, The Journal of Development Studies, 35:5, 162-184, DOI. 
Kallummal, M., Mendiratta, D., \& Samgita, S. (2018). US Import Refusals of Agricultural Products and Their Impact on the Participation of Indian Firms. Journal of Political Economy, 7(I) 78-104.

Kariyasa, K. (2017). Dampak Tarif Impor Dan Kinerja Kebijakan Harga Dasar Serta Implikasinya Terhadap Daya Saing Beras Indonesia Di Pasar Dunia. Analisis Kebijakan Pertanian, 1(4), 315-330.

Kariyasa, K. (2017). Dampak Tarif Impor Dan Kinerja Kebijakan Harga Dasar Serta Implikasinya Terhadap Daya Saing Beras Indonesia Di Pasar Dunia. Analisis Kebijakan Pertanian, 1(4), 315-330.

Malian, A. H., Mardianto, S., \& Ariani, M. (2016). Faktor-faktor yang Mempengaruhi Produksi, Konsumsi Dan Harga Beras Serta Inflasi Bahan Makanan. Jurnal Agro Ekonomi, 22(2), 119146.

Muthayya, S., Sugimoto, J. D., Montgomery, S., \& Maberly, G. F. (2014). An Overview Of Global Rice Production, Supply, Trade, And Consumption. Annals of the New York Academy of Sciences, 1324(1), 7-14.

Norliani, \& Rosada, I...(2015). Rice-Field Conversion and Its Impact on Food Availability. International Conference on Food, Agriculture and Natural Resources Science Procedia 9 (2016) $40-46$.

Rungkat, D. M., Rumagit, G. A., Ngangi, C. R., \& Ruauw, E. (2014, February). Analisis Faktor-faktor yang Mempengaruhi Impor Beras Di Sulawesi Utara. In COCOS (Vol. 4, No. 2).

Santosa, I., Gede, M. A., Ketut, I., \& Dinata, K. (2011). Dampak Alih Fungsi Lahan Sawah Terhadap Ketahanan Pangan Beras.

Sawit, M. H. (2016). Praktek Subsidi Ekspor Beras Di Negara Lain: Mungkinkah Diterapkan di Indonesia?. Analisis Kebijakan Pertanian, 7(3), 231-247.

Seftarita,Chenny.(2014).Kebijakan Ekonomi Makro Dan Siklus Bisnis; Kajian Teori Dan Studi Empiris.Syiah Kuala University Press.Banda Aceh.(No ISBN: 978-602-1270-10-3).

Siringo, H. B., \& Daulay, M. (2014). Analisis Keterkaitan Produktivitas Pertanian Dan Impor Beras Di Indonesia. Jurnal Ekonomi dan Keuangan, 2(8).

Suryana, A., \& Kariyasa, K. (2016, August). Ekonomi padi di Asia: Suatu Tinjauan Berbasis Kajian Komparatif. In Forum Penelitian Agro Ekonomi (Vol. 26, No. 1, pp. 17-31).

Widiarsih, D. (2013). Pengaruh Sektor Komoditi Beras Terhadap Inflasi Bahan Makanan. Jurnal Sosial Ekonomi Pembangunan, 2(6).

Wijayanti, S., Candra, S., \& Sarjono, H. (2011). Analisis Persediaan Beras Nasional Dalam Memenuhi Kebutuhan Beras Nasional pada Perusahaan Umum BULOG. The Winners, 12(1), 82-96. 